\title{
Review
}

Brain, Behavior and Evolution
Brain Behav Evol 2014;84:246-261

DOI: $10.1159 / 000368177$
Received: March 17, 2014

Returned for revision: April 24, 2014 Accepted after revision: September 2, 2014

Published online: November 29, 2014

\section{Predation and the Origin of Neurones}

\author{
Travis Monk Michael G. Paulin \\ Department of Zoology, University of Otago, Dunedin, New Zealand
}

\section{Key Words}

Ecology · Fossils · Molecular phylogeny · Nervous system

evolution · Predation

\begin{abstract}
The core design of spiking neurones is remarkably similar throughout the animal kingdom. Their basic function as fastsignalling thresholding cells might have been established very early in their evolutionary history. Identifying the selection pressures that drove animals to evolve spiking neurones could help us interpret their design and function today. We review fossil, ecological and molecular evidence to investigate when and why animals evolved spiking neurones. Fossils suggest that animals evolved nervous systems soon after the advent of animal-on-animal predation, 550 million years ago (MYa). Between 550 and 525 MYa, we see the first fossil appearances of many animal innovations, including eyes. Animal behavioural complexity increased during this period as well, as evidenced by their traces, suggesting that nervous systems were an innovation of that time. Fossils further suggest that, before $550 \mathrm{MYa}$, animals were either filter feeders or microbial mat grazers. Extant sponges and Trichoplax perform these tasks using energetically cheaper alternatives than spiking neurones. Genetic evidence testifies that ner-
\end{abstract}

vous systems evolved before the protostome-deuterostome split. It is less clear whether nervous systems evolved before the cnidarian-bilaterian split, so cnidarians and bilaterians might have evolved their nervous systems independently. The fossil record indicates that the advent of predation could fit into the window of time between those two splits, though molecular clock studies dispute this claim. Collectively, these lines of evidence indicate that animals evolved spiking neurones soon after they started eating each other. The first sensory neurones could have been threshold detectors that spiked in response to other animals in their proximity, alerting them to perform precisely timed actions, such as striking or fleeing.

๑) 2014 S. Karger AG, Basel

\section{Introduction}

If neurones are the answer, then what was the question? The neurones of millions of species, from dozens of phyla that are quite disparate in other respects, use similar protein channels to create similar action potentials and communicate with other neurones using similar chemicals [Sakarya et al., 2007; Renard et al., 2009; TompkinsMacDonald et al., 2009; Galliot and Quiquand, 2011;

\section{KARGER}

E-Mail karger@karger.com www.karger.com/bbe
Travis Monk

599A Golden Avenue

Elkader, IA 52043 (USA)

E-Mail montr316@student.otago.ac.nz 
Liebeskind et al., 2011]. These core functional features might have been established very early in their evolutionary history. Whatever the question was, ancient animals might have quickly found spiking neurones to be an effective answer. Understanding why they first evolved could help us interpret their function in complex modern nervous systems.

Fossil evidence can reveal much about the timing and circumstances surrounding the evolutionary appearance of spiking neurones. Fossils can reveal not only the morphology of ancient organisms and when they lived, but also their ecology and their behaviour. Fossil evidence indicates that animals started experiencing profound morphological and behavioural changes just before the Cambrian explosion. Within 20 million years, simple and defenseless animals had developed weapons and armour. The earliest direct and indirect fossil evidence for nervous systems is dated to about this time, suggesting that spiking neurones were another such development.

Fossil evidence also informs us about the ecological conditions of the distant past. Evolutionary change takes place in a context of contingent climatic, geochemical and biotic affordances, in which it is difficult to assign causality [Gibson, 1979; Chemero, 2003]. Affordances are conditions that allow, but do not require, organisms to undergo evolutionary change. For example, animals cannot evolve spiking neurones if their genomes do not allow them to do so (i.e. if the genetic affordance is absent). However, even if the genetic affordance for spiking neurones is present, animals may still not evolve them if ecological affordances remain absent. Animals would not evolve spiking neurones, even if they could, unless there was an ecological benefit to compensate the cost of developing and operating them. Establishing when an ecological affordance for spiking neurones appeared is central to identifying when they evolved.

Modern molecular genetics has revolutionised our understanding of the relatedness of animals, their nervous systems and when lineages diverged. Molecular evidence indicates that all nervous systems share a degree of genetic conservation [Ghysen, 2003; Gomez-Skarmeta et al., 2003; Ball et al., 2004; Matus et al., 2006; Denes et al., 2007; Jacobs et al., 2007; Arendt et al., 2008; Watanabe et al., 2009; Hirth, 2010], but some nervous systems are more closely related than others. Any argument for when animals evolved nervous systems must offer an explanation for the varying degrees of genetic conservation that we observe in nervous systems from different lineages.

Predation and the Origin of Neurones

This paper reviews fossil, ecological and molecular evidence, and discusses what each tells us about when and why animals first evolved spiking neurones.

\section{Fossils and the Morphology and Behaviour of Ancient Animals}

The fossil record shows that animals experienced profound changes in their morphology and behaviour between 550 and 525 million years ago (MYa).

Figure 1 shows body fossils of putative animals before, during and after this 25-million-year period. Most animals before 550 MYa probably have no descendants that exist today. The taxonomic classification of those fossils is notoriously difficult, even at the kingdom level [Narbonne, 2005; Conway-Morris, 2006; Xiao and Laflamme, 2008]. Sponges are one of the few extant animals we can recognise in the body fossil record before $550 \mathrm{MYa}$. The oldest fossil evidence for animal existence are body fossils from Namibia that are interpreted as sponges, dated to 760 MYa [Brain et al., 2012]. The chemical fossil record also supports an ancient presence of sponges, with demosponge biomarkers dated to $635 \mathrm{MYa}$ [Love et al., 2009]. Other putative animals called rangeomorphs appeared between 575 and 560 MYa. Rangeomorphs were frondlike and superficially resembled modern sea pens, though their taxonomic affinity remains unknown [Laflamme and Narbonne, 2008].

Between 560 and $550 \mathrm{MYa}$, we see a notable increase in animal taxonomic diversity. Bilaterally symmetric animals such as Dickinsonia, Yorgia and Kimberella appear, as do animals with tri-, tetra-, penta- and octaradial symmetry such as Tribrachidium, Conomedusites, Arkarua and Eoandromeda [Droser et al., 2006; Xiao and Laflamme, 2008; Tang et al., 2011]. Other animals such as Parvancorina show clear anterior-posterior differentiation. While these animals exhibited various symmetries and rudimentary body patterning, they were morphologically very unlike extant animals [Valentine, 2002], as shown in figure 1.

Around $550 \mathrm{MYa}$, almost all of these simple animals disappear from the fossil record. By $525 \mathrm{MYa}$, they had been replaced by more complex animals that are recognisable as representatives of extant animal phyla [Valentine, 2002; Narbonne, 2005]. During this time, which includes the Cambrian explosion, we see the appearance of many evolutionary innovations such as calcified skeletons and drills (550 MYa) [Bengtson and Zhao, 1992; Hua et al., 2003], plates and shells (541-530 MYa) [Maloof et 


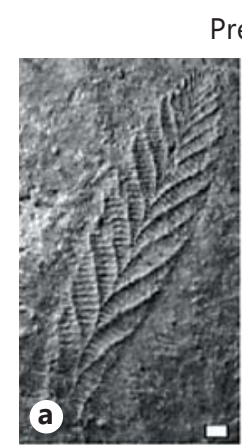

Pre-560 MYa
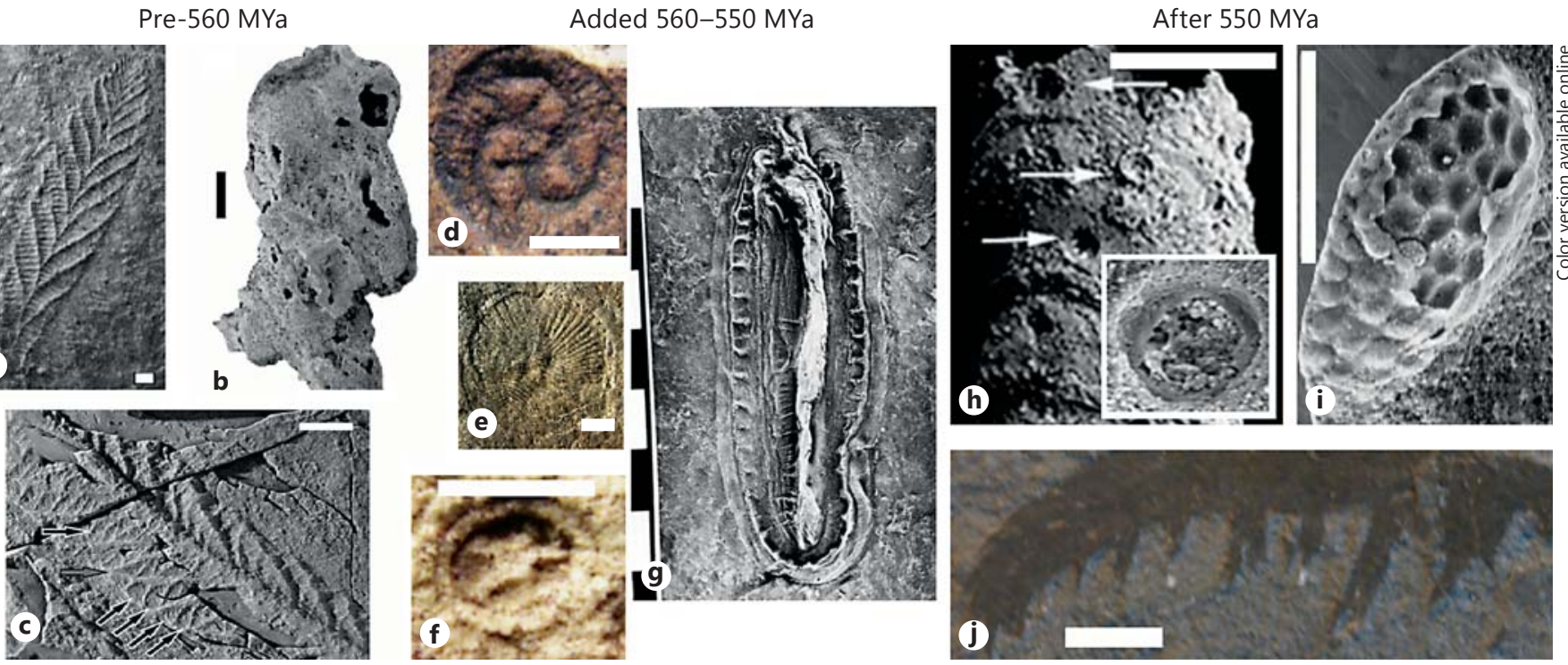

Fig. 1. Animals experienced profound morphological innovations starting at around 550 MYa. a-g Soft, defenceless animals. h-j Skeletons, nervous systems and spiked tentacles. a-c The earliest animals were almost exclusively sessile filter feeders. a The frond Charnia masoni, dated $\sim 570 \mathrm{MYa}$. Scale bar $=1 \mathrm{~cm}$. b Putative sponge body fossil, the oldest known evidence of animals, dated 760 MYa. Scale bar $=0.1 \mathrm{~mm}$. c Charnia wardi specimen with rangeomorph elements (grey arrow) and primary branches (black arrows) still intact, dated $\sim 575 \mathrm{MYa}$. Scale bar $=1 \mathrm{~cm}$. d-f Various symmetries of animals appeared after $560 \mathrm{MYa}$. Scale bar $=1 \mathrm{~cm}$. d Triradial body plan of Tribrachidium. e Bisymmetric Dickinsonia.f Pentaradial Arkarua.g Exquisitely preserved specimen of the possible bilaterian Kimberella. Scale bar $=1-\mathrm{cm}$ increments. h-j Between 550 and 525 MYa, animal morphology changed significantly. $\mathbf{h}$ Bore holes in the calcified skeleton of a putative cnidarian Cloudina. This image is the oldest known evidence for macrophagy, and amongst the oldest evidence for skeletons and drills (white arrows). Scale bar $=150 \mu \mathrm{m}$. Inset A close-up of one of the holes. i SEM image of a trilobite eye from the lower Cambrian. Scale bar $=0.1 \mathrm{~mm}$. $\mathbf{j}$ The spiked tentacle of Anomalocaris, a lowerCambrian predator. Scale bar $=2 \mathrm{~mm}$. Images taken from Laflamme and Narbonne [2008] (a), Brain et al. [2012] (b), Laflamme et al. [2007] (c), Xiao and Laflamme [2008] (d-f), Fedonkin et al. [2007] (g), Hua et al. [2003] (h), Clarkson et al. [2006] (i) and Wikipedia Commons (j). All images reproduced with permissions. al., 2010; Erwin et al., 2011], and spikes, teeth and jaws (530 MYa; fig. 1).

Nervous systems might have been another innovation from this era; the oldest known direct evidence for nervous systems appears at $525 \mathrm{MYa}$ as the eyes of various arthropods [Clarkson et al., 2006; Zhang and Shu, 2007; Paterson et al., 2011]. These eyes were well developed, suggesting that they had already existed for an evolutionarily significant amount of time. Some of these innovations are shown in figure 1 .

As animal bodies increased in complexity, so too did their behaviour. Trace fossils are fossils of biological activity on a substrate. They are good indicators of animal behaviour and ecological change [Mangano and Buatois, 2007; Bengtson and Rasmussen, 2009; Plotnick, 2012]. Figure 2 shows examples of animal traces before and after $550 \mathrm{MYa}$. The first indisputable animal trace fossils appear around $560 \mathrm{MYa}$ [Budd and Jensen, 2000; Jensen,
2003; Seilacher et al., 2005; Liu et al., 2010]. For 10 million years, the vast majority of these first trace fossils were unbranched, simple, horizontal traces [Jensen, 2003; Jensen et al., 2005; Liu et al., 2010]. The shallowness of these traces indicates that they were probably caused by a bilaterian pushing through the sediment, forming ridges on either side [Jensen et al., 2006]. Other traces from this era include repeated imprints of Yorgia [Ivantsov and Malakhovskaya, 2002] and Dickinsonia [Xiao and Laflamme, 2008], which may (or may not [McIlroy et al., 2009]) have been capable of passive intermittent movement. Kimberella seemed to move itself actively on microbial mats, scratching the mats where it pleased [Seilacher et al., 2005; Mangano and Buatois, 2007; Peterson et al., 2008].

At $550 \mathrm{MYa}$, animal traces became noticeably more complex and diverse, just as body fossils did. Figure 2 shows pictures of bilaterian trace fossil evidence dated 551-541 MYa. Instead of pushing themselves through 

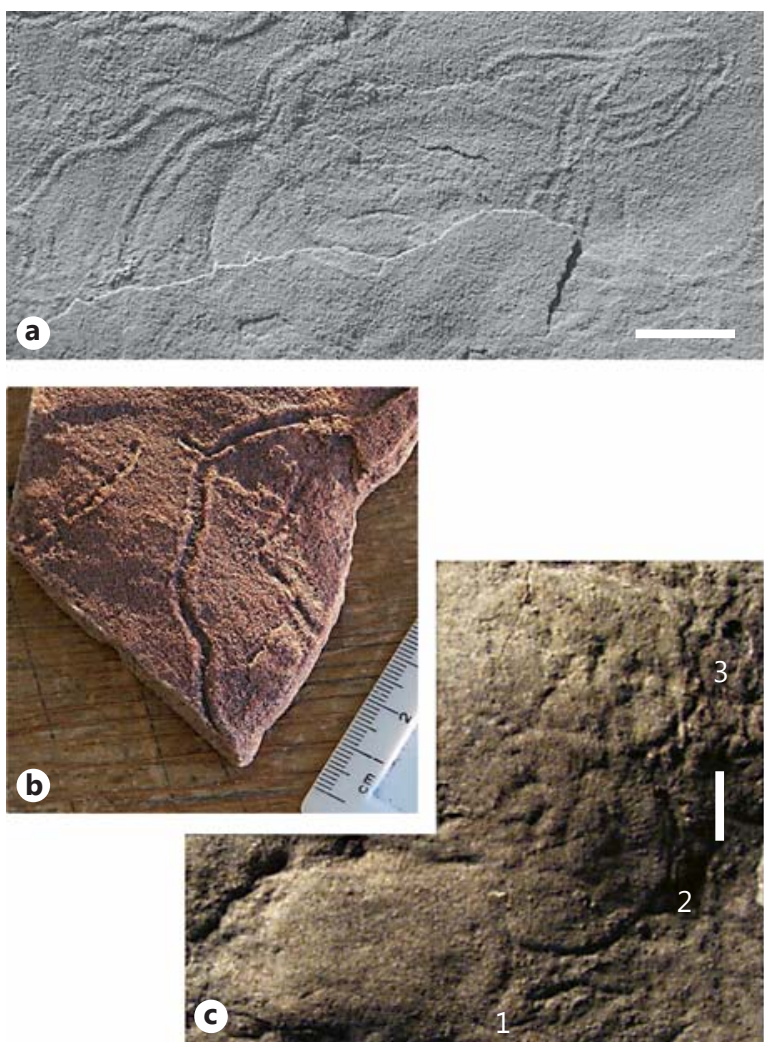

Fig. 2. Animal traces increased in complexity and diversity in parallel with animal morphology. There are no known, indisputable trace fossils dated before 560 MYa. a Archeonassa: ridges on either side of the trace indicate displacement by pushing sediment up either side, presumably by a bilaterian. Scale bar $=1 \mathrm{~cm}$. b Helminthoidichnites are simple, unbranched, horizontal traces that form the majority of animal traces from this era. c Series of three Dickinsonia resting traces, 1 marks the oldest and 3 the youngest, presumed to have been made by the same organism. Scale bar $=1 \mathrm{~cm}$. d-f More complex animal behaviour at the end of the pre-Cambri-
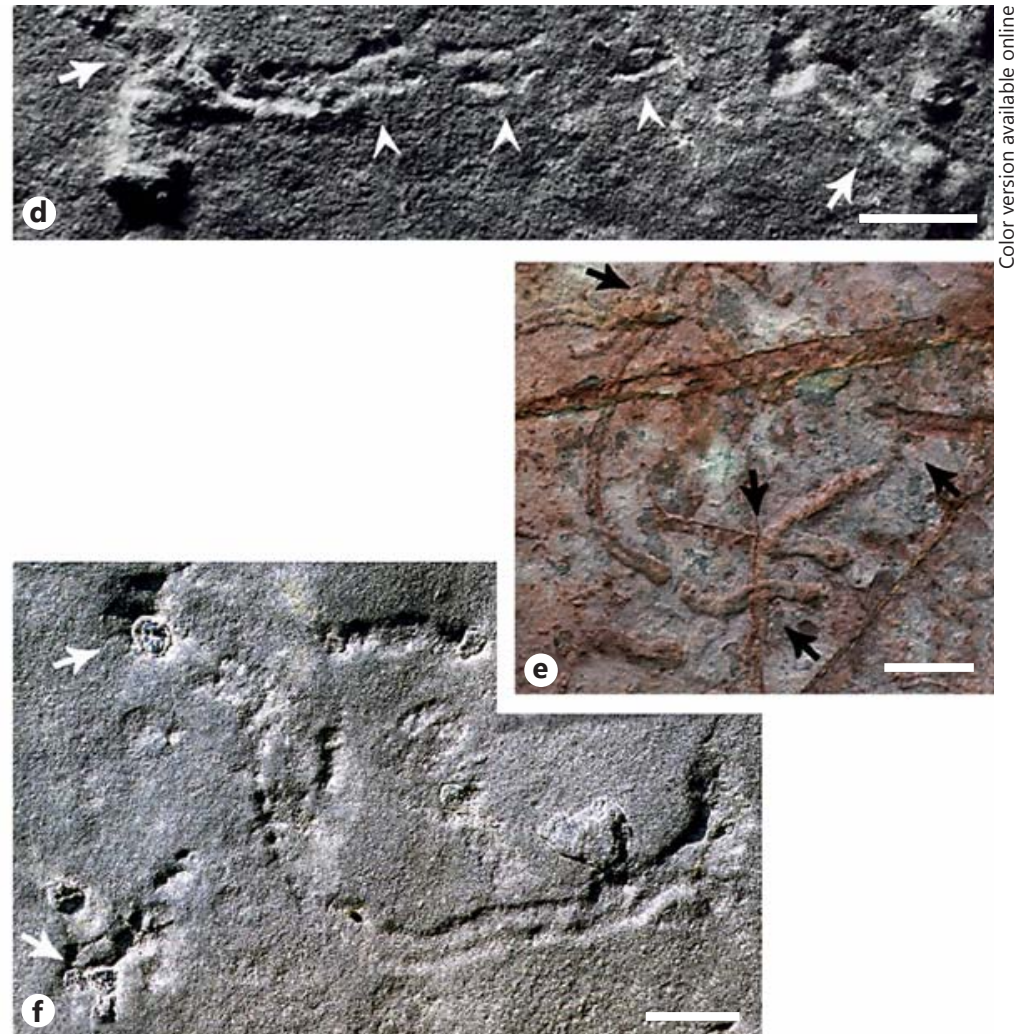

an. d Surface tracks and scratch marks (white arrowheads) connecting full reliefs of tunnels (white arrows). Scale bar $=1 \mathrm{~cm}$. e Horizontal, cross-cutting, under-mat tunnels. The black arrows denote cross-cutting tunnels. Scale bar $=2 \mathrm{~cm}$. $\mathbf{f}$ Vertical structures (arrows) connected by horizontal tunnels. Scale bar $=1 \mathrm{~cm}$. For more beautiful pictures of late pre-Cambrian animal trace fossils, see Jensen et al. [2006]. Images taken from Jensen [2003] (a), Wikipedia Commons (b), Xiao and Laflamme [2008] (c) and Chen et al. [2013] (d-f). All images reproduced with permissions.

\section{Ancient Animal Ecology and an Affordance for Nervous Systems}

Neurones are highly specialised and energetically expensive cells [Laughlin et al., 1998; Laughlin, 2001; Niven et al., 2007; Niven and Laughlin, 2008]. Many examples of nervous system reduction have been interpreted as a consequence of the energetic expense of neural tissue. Some ascidian [Cloney, 1982] and anthozoan [Ball et al., 2004] larvae disassemble their nervous system after their metamorphosis into sessile adults. There are many examples of cave-dwelling species that have lost their eyes and much of their visual processing centres [Niven and 
Laughlin, 2008]. These observations suggest that nervous systems could not have evolved unless they provided some substantial ecological benefit to compensate for their expense.

The simple morphology and behaviour of pre-Cambrian animals were likely a reflection of their simple ecological lifestyle. Before $560 \mathrm{MYa}$, it seems that animals were exclusively sessile filter feeders (e.g. sponges and frond-like rangeomorphs) [Narbonne, 2005; Bottjer and Clapham, 2006; Laflamme and Narbonne, 2008]. These animals might have experienced many ecological selection pressures that extant sessile animals face, such as dispersal strategies, intraspecific competition and epifaunal tiering [Clapham and Narbonne, 2002; Clapham et al., 2003; Droser et al., 2006]. The bi-, tri-, tetra-, penta- and octaradial taxa existing between 550 and 560 MYa probably exploited the abundant microbial mats or suspension fed in the water column for nutrients [Seilacher, 1999; Bottjer and Clapham, 2006; Tang et al., 2011], each occupying a specific ecological niche [Seilacher, 1999].

Animals apparently did not eat each other (macrophagy) throughout almost all of the pre-Cambrian [McMenamin, 1986; Waggoner, 1998; Clapham et al., 2003; Hua et al., 2003; Narbonne, 2005; Xiao and Laflamme, 2008; Northcutt, 2012; Sperling et al., 2013]. The fossil record is notoriously incomplete, but excellent pre-Cambrian taphonomic conditions [Bottjer and Clapham, 2006] preserved a surprising number of body and trace fossils from hundreds of species, some of which are globally distributed [McCall, 2006; Shen et al., 2008; Xiao and Laflamme, 2008]. None of those pre-Cambrian fossils reveal evidence of injuries, healed wounds, body fragments, trace fossils or functional interpretations of body parts that are consistent with the existence of macrophagy (e.g. shells and drills) [McMenamin, 1986; Waggoner, 1998; Clapham et al., 2003; Hua et al., 2003; Narbonne, 2005; Xiao and Laflamme, 2008; Northcutt, 2012; Sperling et al., 2013]. Furthermore, survivorship curves of pre-Cambrian animals imply age-independent mortality and are consistent with a lack of predation [Waggoner, 1998]. It is possible that macrophagy has a substantial pre-Cambrian history, but evidence for its practise escaped the fossil record, e.g. if the earliest predators and prey were exclusively pelagic. However, such scenarios would require an explanation for why the soft, defenceless, slow animals on the benthos remained unexploited.

In the absence of macrophagy, pre-Cambrian animals would have only needed to move according to nutritional, chemical, light or temperature gradients [Bengtson, 2002] and filter water or forage for sustenance. Extant sponges and Trichoplax indicate that animals do not require neurones to accomplish these tasks. Extant sponges and their larvae show that animals do not require neurones to filter feed [Leys et al., 1999; Leys and Meech, 2006; Nickel, 2010; Ludeman et al., 2014]. Trichoplax demonstrates that animals do not require neurones to crawl on a substrate and forage for food [Schierwater, 2005; Pearse and Voigt, 2007; Liebeskind et al., 2011]. Sponge larvae show that animals do not require neurones to follow gradients or respond to environmental stimuli [Woollacott, 1993; Leys et al., 2002; Maldonado, 2006; Ettinger-Epstein et al., 2008; Wahab et al., 2011; Rivera et al., 2012]. There are cheaper alternatives than neurones to fulfil these tasks.

Figure 3 contains examples of such cheaper alternatives. Many sponge larvae possess a ring of cells with long cilia. The distal protrusions of these cells are filled with pigment and mitochondria [Maldonado et al., 2003] and express a sponge gene that was shown to be photoresponsive [Rivera et al., 2012]. These cells collectively form a rudimentary eye and steer larvae according to light intensity [Maldonado, 2004]. Cilia lining the osculum of freshwater sponges are probably sensory cells that trigger body contractions in response to changes in expelled water flow [Ludeman et al., 2014]. Globular cells protrude from the epithelia of almost all sponge larvae and probably serve neurone-like functions by secreting chemicals in response to stimuli (i.e. paracrine signalling) [Woollacott, 1993; Richards et al., 2008]. Neurones are not the only cell type that animals could utilise for sensory capabilities.

The fossil record indicates that a major event in the evolutionary history of animals occurred at around 550 MYa: the introduction of macrophagy. Unmistakable bore holes in the calcified sessile animal Cloudina are currently the oldest evidence of animals eating each other, with fossils dated at $550 \mathrm{MYa}$ (fig. 1h) [Bengtson and Zhao, 1992; Hua et al., 2003]. Subsequently, and perhaps not coincidentally, the vast majority of defenceless filter feeders and mat grazers (fig. 1a-g) disappeared from the fossil record [Waggoner, 2003; Narbonne, 2005; Xiao and Laflamme, 2008], replaced instead by animals with weapons and armour.

Still, the first predator-prey interactions did not necessarily require neurones. All animals emit mechanical, chemical, electrical and other signals in their vicinity, and other animals could have detected that signal and followed its gradient toward its source (or away from it). As sponge larvae show, animals do not require neurones to follow gradients or respond to stimuli [Leys et al., 2002; Maldonado, 2006; Ettinger-Epstein et al., 2008; Wahab et 

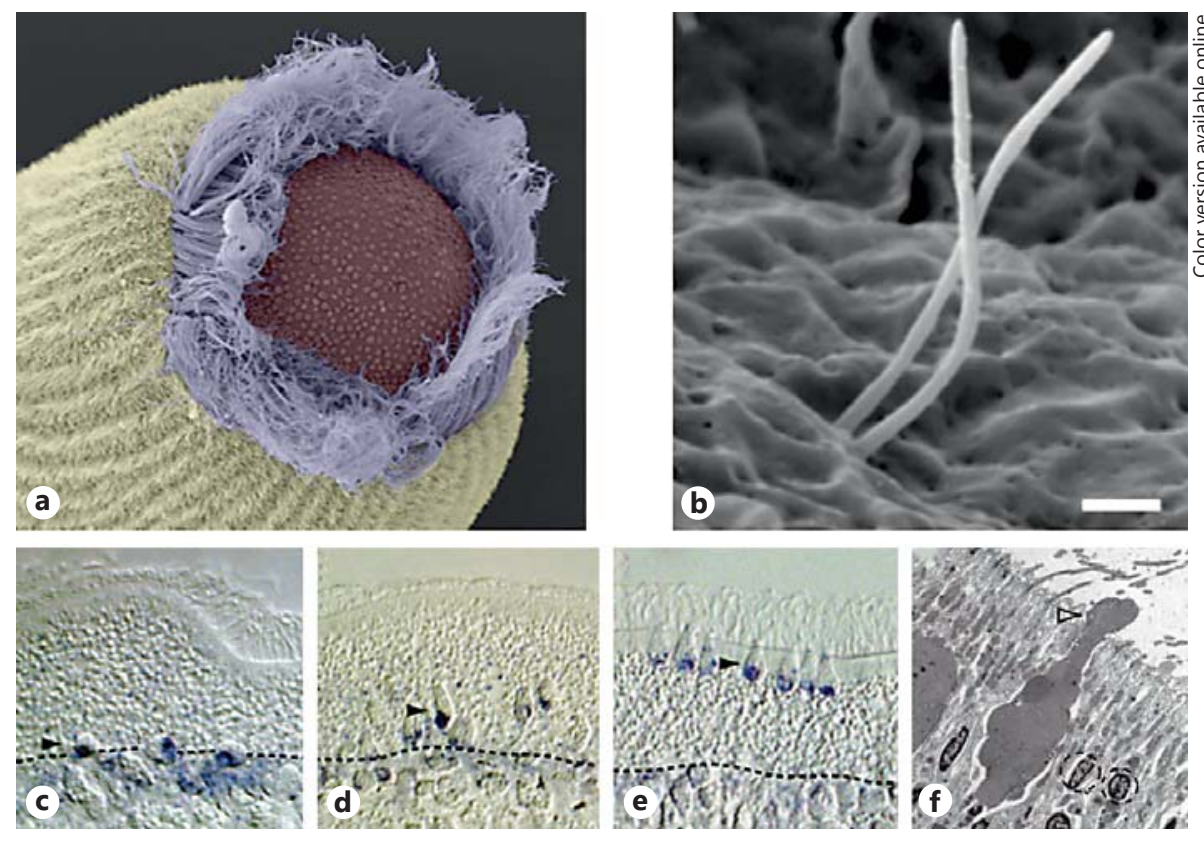

Fig. 3. Sponges do not have neurones, but they do have specialised cells that can detect stimuli. a General view of Amphimedon queenslandica (demosponge) larvae. The ring of long-ciliated cells at the posterior end of the larvae are pigmented, facilitating phototaxis. b Sensory cilia line the osculum of the freshwater sponge Ephydatia muelleri and trigger body contractions in response to changes in the flow of expelled water. Scale bar $=1 \mu \mathrm{m}$. c-f Globular cells (black arrowheads) migrating through the epithelium of an Amphimedon larvae (c-e) until they eventually protrude from the epithelium. These globular cells express genes that suggest that these cells are ancient animal sensory devices. $f$ TEM image of a globular cell of an Amphimedon larva. The apex of the cell protrudes into the environment (open arrowhead). Images taken from Sally Leys (photo credit; a), Ludeman et al. [2014] (b) and Richards et al. [2008] (c-f). All images reproduced with permissions. al., 2011; Rivera et al., 2012]. In fact, unicellular organisms [Berg, 1975] and plants [Trewavas, 2005] can also perform these feats without the aid of neurones. The earliest predators and prey could have utilised similar nonneural sensory capabilities to follow gradients in pursuit or retreat of one another.

While the first predator-prey interactions probably transpired slowly by modern standards, macrophagy must have pressured animals to detect and react to other animals increasingly quickly. Over evolutionary time, animals must have decreased their reaction times and moved ever faster when other animals approached them. Eventually, their success in predator-prey interactions depended on events that happen on a millisecond time scale.

Extant nervous systems can make decisions on a millisecond time scale [Johansson and Birznieks, 2004; Bodelon et al., 2007; Olberg et al., 2007; Stanford et al., 2010; Stewart et al., 2013]. This reaction time may reflect a biophysical limit on the speed at which biological cells can create and process signals. Predation still pressures extant animals to detect and react to the proximity of other animals as quickly as possible; if they could react on a microsecond or nanosecond time scale, then we expect that they would. However, faster reaction times may not be biologically possible, in which case reaction times have achieved their biophysical limit.

Macrophagy pressures animals to react to threats and opportunities in a precisely timed and well-coordinated way [Broom and Ruxton, 2005; Chittka et al., 2009; Zylberberg and DeWeese, 2011; Stewart et al., 2013]. Neurones can create more precisely timed signals than paracrine-signalling sponge-like 'proto-neurones'. Networks of neurones can propagate those signals throughout a body quickly, facilitating well-coordinated behaviours. In predator-prey interactions, these abilities are ecological benefits that could compensate the energetic expense of nervous systems. 


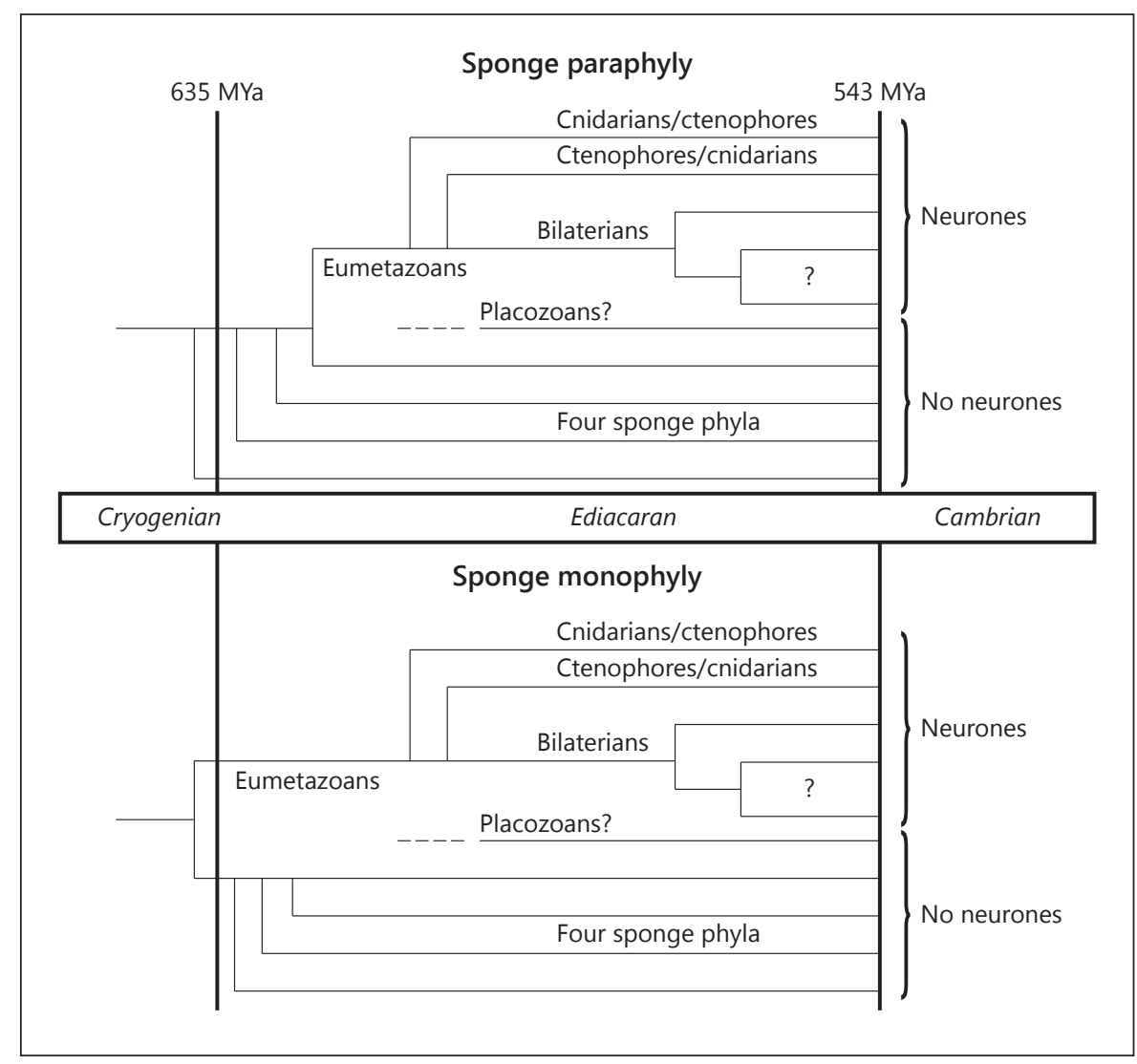

Fig. 4. Conflicts and consensus of basal animal phylogeny. Conflicts: We do not know the most basal extant animal lineage. This figure depicts sponges as the most basal extant lineage, but a few studies have reported placozoans or ctenophores instead. We do not know whether sponges are paraphyletic (top cladogram) or monophyletic (bottom cladogram). If sponges are paraphyletic and the most basal lineage, then all animals with nervous systems must have descended from a sponge. We do not know how placo- zoans relate to the other clades. We do not know if cnidarians or ctenophores are more basal. We also do not know how many bilaterian phyla crossed the Ediacaran-Cambrian boundary. Consensus: cnidarians, ctenophores, bilaterians, placozoans and sponges comprise the basal animal lineages. Bilaterians are the most derived of these lineages. These lineages split before the Cambrian explosion.

\section{Basal Animal Phylogeny and Divergence Times}

We now introduce the basal animal lineages and present fossil and molecular evidence on when those lineages diverged. In the next section, we will review what is known about the genetic relatedness of nervous systems in those lineages and what we can deduce from that relatedness about when nervous systems evolved.

Phylogenetics has provided insight into the relatedness of animal lineages, but published results of basal animal relatedness are notoriously inconsistent. Nearly every possible branching order of basal animal lineages has been reported (see Nielsen [2008] for a compilation of such results). Furthermore, incompatible trees are each reported with disturbingly high confidence [Siddall, 2010].

Despite this inconsistency, basal animal phylogenetic studies are in broad agreement on several key points, as illustrated in figure 4. All studies agree that the basal animal lineages comprise poriferans (sponges), placozoans (Trichoplax), cnidarians (stinging jellyfish), ctenophores (comb-sieving jellyfish) and bilaterians (three germ layers and bilateral symmetry). Most studies agree that these basal lineages all descended from one common ancestor [Borchiellini et al., 2001; Muller, 2001, 2003; Nielsen, 2008]. Most studies report Porifera as the most basal extant animal lineage, as reviewed by Nielsen [2008], though others have reported Placozoa [Dellaporta et al., 2006] or 
Ctenophora [Dunn et al., 2008; Ryan et al., 2013; Moroz et al., 2014]. Almost all agree that cnidarians and ctenophores are basal to or sisters of bilaterians [Peterson and Eernisse, 2001; Manuel et al., 2003; Glenner et al., 2004; Wallberg et al., 2004], and that sponges, cnidarians, ctenophores and several bilaterian phyla crossed the EdiacaranCambrian boundary $543 \mathrm{MYa}$ [Halanych, 2004; Peterson et al., 2004, 2005; Peterson and Butterfield, 2005].

A current and important conflict concerns the monophyly [Peterson and Eernisse, 2001; Wallberg et al., 2004; Phillippe et al., 2009] versus paraphyly [Borchiellini et al., 2001; Peterson and Eernisse, 2001; Manuel et al., 2003; Halanych, 2004; Peterson et al., 2005; Sperling et al., 2012] of sponges. If sponges are paraphyletic, then all animals with nervous systems must have descended from a sponge, as shown in figure 4 . We will later discuss why this issue is of particular importance to nervous system evolution.

Fossils and molecular clock studies give different answers as to when these basal animal lineages diverged. While taxonomic classification of pre-Cambrian animal fossils is highly controversial, fossil evidence tentatively suggests that cnidarians, ctenophores and bilaterians split from each other by 550 MYa. Eoandromeda is interpreted as an early ctenophore, as it possesses characteristics observed exclusively in the Ctenophora phylum [Tang et al., 2011]. It appeared no later than 560-550 MYa [Xiao and Laflamme, 2008; Zhu et al., 2008]. There are many fossil candidates for the existence of cnidarians at this time, including Palaeophragmodictya spinosa [Serezhnikova, 2007], axially patterned fronds [Erwin, 2008] and calcified Cloudina and Namacalathus (fig. 1) [Cortijo et al., 2010; Gaucher and Germs, 2010; Wood, 2011]. Kimberel$l a$ is perhaps the strongest body fossil evidence that bilaterians existed before $550 \mathrm{MYa}$, though the existence of bilaterally symmetric organisms does not necessarily imply that those organisms were bilaterians [Ball et al., 2004; Matus et al., 2006]. Trace fossils dated at 551-543 MYa reflect peristaltic locomotion, indicating the presence of bilaterians [Mangano and Buatois, 2007; Chen et al., 2013]. A conservative reading of the body fossil and trace fossil records suggests that basal animal clades, including ctenophores, cnidarians and bilaterians, had diverged by 550 MYa [Jensen et al., 2005].

Molecular clock studies are another source of evidence regarding when these lineages diverged. Though molecular clock methodology has improved in recent years, they can still be sensitive to methodology, model assumptions and the taxa included in the data set [Welch et al., 2005; Northcutt, 2012]. Recent molecular clock studies still vary widely in their reported branching times, and molecular clocks become increasingly unreliable as they attempt to estimate older branching times [Marshall and Valentine, 2010]. However, molecular clock studies assert an earlier divergence of these lineages than the fossil record indicates. Current molecular clock estimates for the branching time of cnidarians from bilaterians range from 700 to $600 \mathrm{MYa}$ [Peterson et al., 2004, 2005; Erwin et al., 2011]. Estimates for the branching time of bilaterians into protostomes and deuterostomes range from 670 to $570 \mathrm{MYa}$ [Aris-Brosou and Yang, 2003; Peterson et al., 2004, 2005; Erwin et al., 2011].

\section{Genetic Relatedness of Nervous Systems}

Modern molecular genetics has revolutionised our understanding of relatedness, but we must be careful in our interpretation of such evidence. As we will soon discuss, all nervous systems share some degree of genetic conservation. Therefore, the last common ancestor of animals developing nervous systems possessed those conserved genes, and it is tempting to infer that this ancestor must have used them to develop a nervous system as well. This inference is not necessarily true; there are many counterexamples of genes that have some conserved function in a number of 'higher' lineages, but have a different function in more basal lineages [Marshall and Valentine, 2010].

Sponges and Trichoplax provide examples of this principle that are specific to nervous systems. Sponges have many genes that are related to important neural genes in 'higher' animals. Comprehensive lists of these genes exist [Renard et al., 2009]. A few can be transferred into bilaterians and successfully function in neurogenic roles [Richards et al., 2008]. Sponges possess a 'nearly complete' set of post-synaptic proteins [Sakarya et al., 2007], potassium ion channels [Tompkins-MacDonald et al., 2009], and many known neurotransmitters and neuromodulators [Renard et al., 2009]. Trichoplax contains genes involved in neurone specification (and muscle and circulatory system development) [Schierwater et al., 2008; Srivastava et al., 2008; Marshall and Valentine, 2010]. Neither sponges nor Trichoplax have neurones (or muscles or circulatory systems); those genes must serve some other purpose for them. The molecular genetics of sponges and Trichoplax show that the presence of conserved neurogenic genes in conserved neurogenic roles in 'higher' animals does not necessarily imply the presence of neurones in their ancestors. 


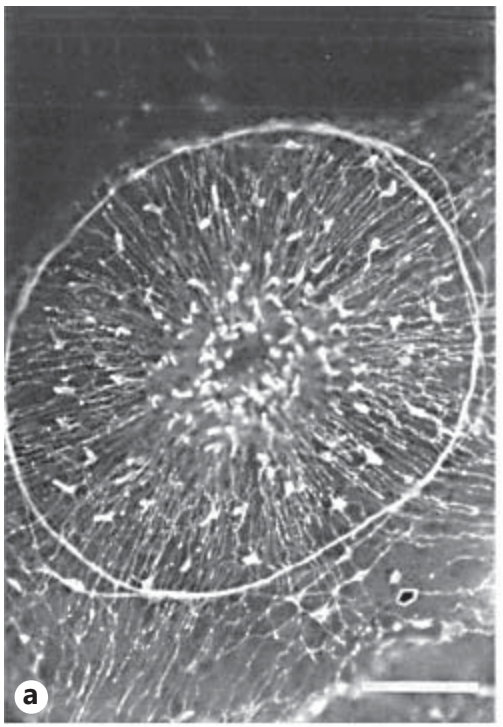

b

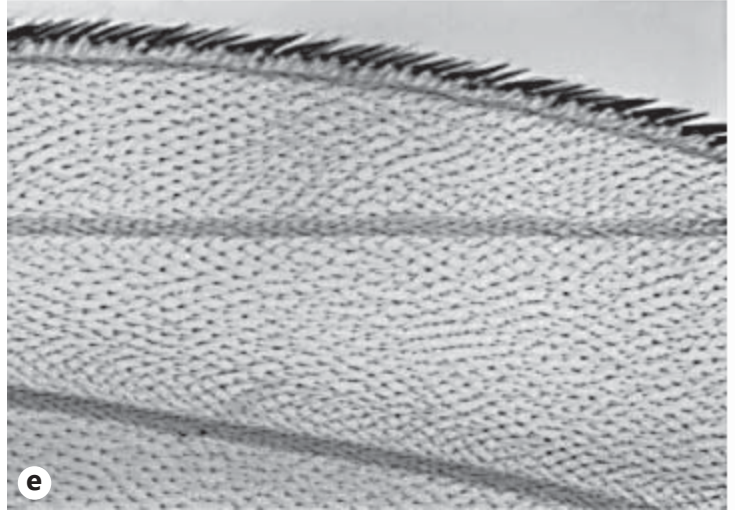

Cnidarian Vertebrate<smiles>O=C1CCCCC1</smiles>

Hyzic

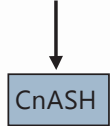

CnASH

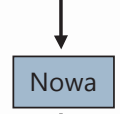

Nematocyte

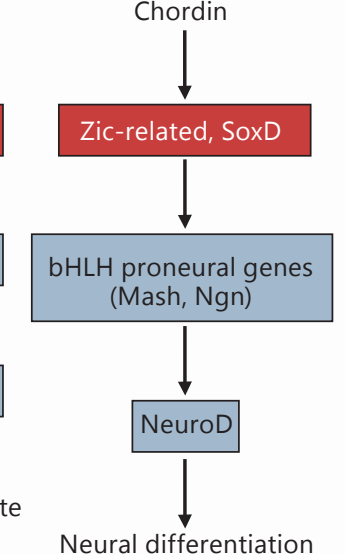

Neural differentiation
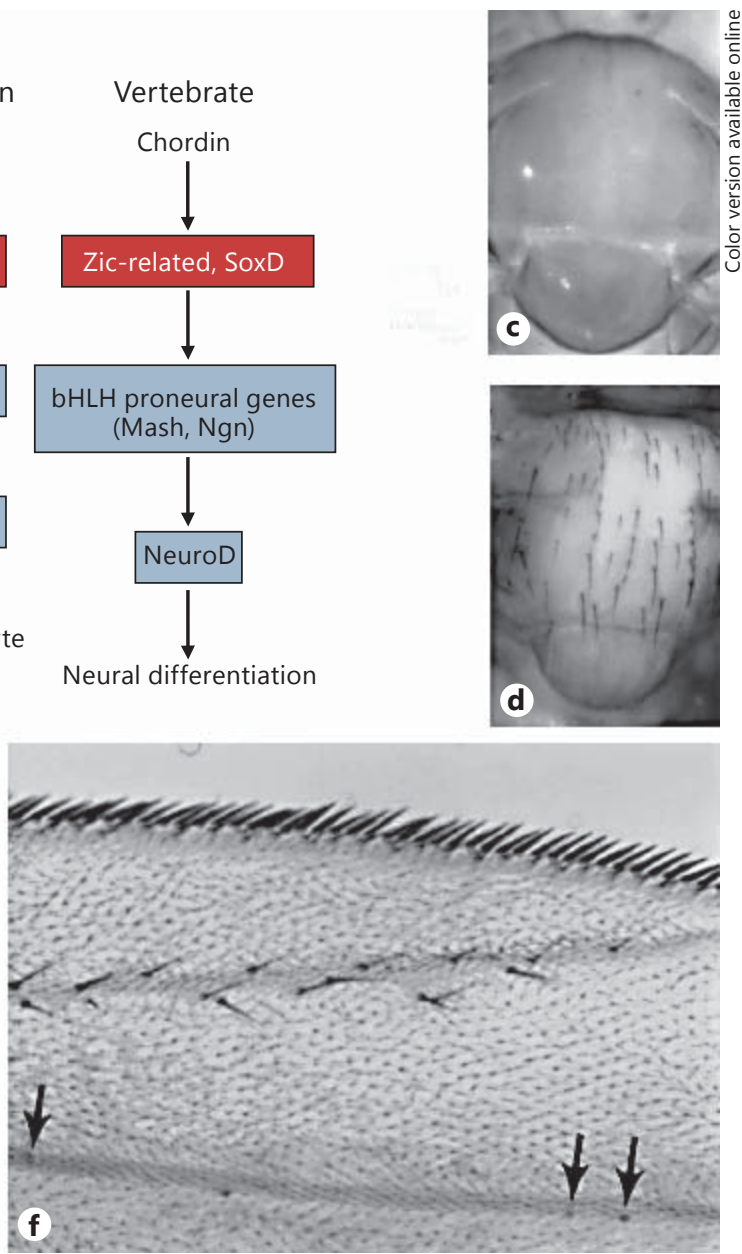

Fig. 5. Evidence for the genetic conservation of nervous system development between cnidarians and bilaterians. a Oral region of Hydra oligactis (cnidarian), showing the nerve ring that connects to tentacles and a dense population of epidermal sensory cells surrounding the mouth (centre). Concentrations of neurones in specific regions of the body plan are reminiscent of neural regionalisation in bilaterians. Scale bar $=100 \mu \mathrm{m}$. b The genetic pathway leading to neural differentiation in Hydra (cnidarian) and vertebrates (chordate) share some genetic homologues (top two boxes), but not others (lowest box). c-f Injecting a cnidarian proneural gene into Drosophila (a bilaterian) induces the development of sensory structures. c Control Drosophila thorax. d Mechanoreceptor bristles on Drosophila thorax induced. e Control Drosophila wing. f Bristles and chemoreceptors (black arrows) induced. Images taken from Koizumi et al. [1992] (a), Lindgens et al. [2004] (b) and Grens et al. [1995] (c-f). All images reproduced with permissions.
Sponges possess much of the core molecular toolkit required to develop a nervous system. If sponges are paraphyletic (fig. 4), then all other animals must have inherited that toolkit from their sponge ancestor. If sponges are monophyletic, then it remains likely that all other animals inherited a similar toolkit from some sponge-like predecessor. Either way, one might expect to observe a degree of genetic conservation in the nervous systems of 'higher' animals. Indeed, figure 5 contains examples of genetic similarities we observe in the nervous systems of cnidarians and bilaterians, including genetic homologies be- tween the two lineages [Hayakawa et al., 2004; Lindgens et al., 2004; Matus et al., 2006; Jacobs et al., 2007; Galliot et al., 2009; Marlow et al., 2009; Watanabe et al., 2009]. These observations have led to a widespread belief that cnidarian and bilaterian neurones are genetically homologous.

While all nervous systems share a degree of genetic conservation, those of cnidarians and bilaterians display many disparities that collectively lead to 'strikingly different' overall nervous system organisations [Nakanishi et al., 2012]. The nervous systems of bilaterians contain gli- 


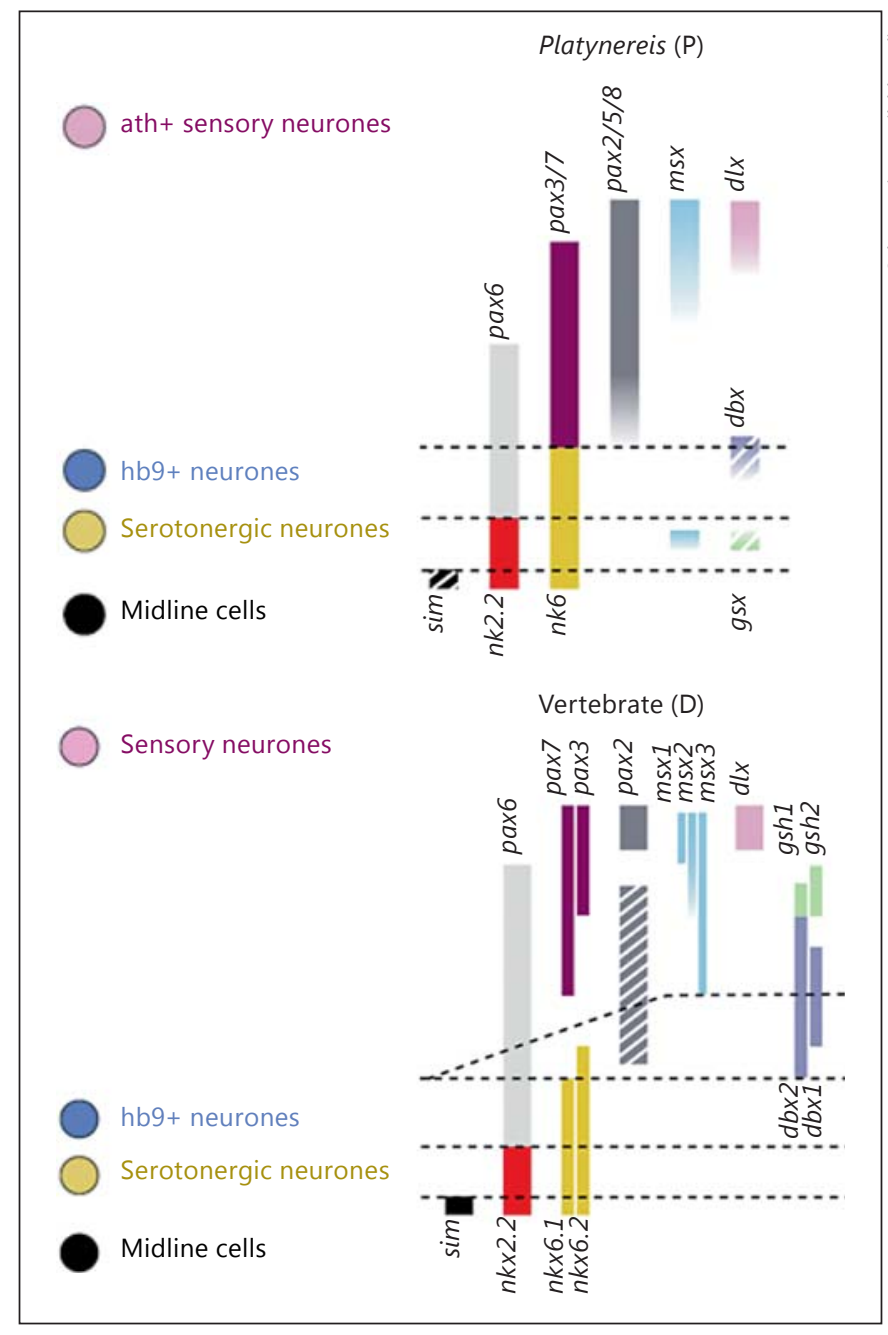

Fig. 6. Mediolateral neurogenic domains between annelid (protostome, P) and vertebrate (deuterostome, D) trunk nervous systems. Vertical bars represent mediolateral domains of neural specification gene expression during development. Homologous genes are vertically aligned; for example, pax3/7 in Platynereis is located directly above pax 3 and pax 7 in the vertebrate. Horizontal dashed lines represent spatial domains with distinct combinations of neural specification gene expression. The resultant neurone types and their spatial distributions are highly conserved, as indicated in the margins. The expression of homologous neurogenic genes in similar spatial distributions in protostomes and deuterostomes is strong evidence that nervous systems evolved exactly once in bilaterians. Figure taken from Denes et al. [2007] and reproduced with permission.

al cells, but no analogous cell types have been reported in cnidarians or ctenophores [Galliot et al., 2009; Marlow et al., 2009]. During development, only the ectoderm of bilaterians shows neurogenic potential, whereas neurones may arise from both the ectoderm and the endoderm in cnidarians [Galliot et al., 2009; Marlow et al., 2009; Nakanishi et al., 2012]. Furthermore, the development of the endodermal and ectodermal nervous systems in cnidarians occur through independent guidance mechanisms [Nakanishi et al., 2012]. No shared 'pan-neural' genes have been reported in cnidarians and bilaterians [Moroz, 2009]. Even within the cnidarian phylum, no pan-neural markers have been shown to cross-hybridise between cnidarian species [Galliot and Quiquand, 2011]. On this basis, it has been suggested that not only did nervous systems evolve independently in bilaterians and cnidarians, but perhaps even several times in the cnidarian phylum alone [Moroz, 2009].

In bilaterians, nervous systems are highly genetically conserved, as shown in figure 6. All known bilaterians utilise conserved genes that are expressed in conserved spatial patterns to develop specific neural types in specific regions of their bodies [Gomez-Skarmeta et al., 2003; Lowe et al., 2003; Denes et al., 2007; Arendt et al., 2008]. Many of these genes can be transferred between disparate bilaterian lineages and function successfully. This molecular evidence strongly suggests that the last common ancestor of all bilaterians also had a nervous system, i.e. bilaterians evolved nervous systems exactly once [Hirth, 2010].

\section{Discussion}

\section{Summary}

We have reviewed fossil, ecological and molecularcomparative evidence to see what each tells us about when and why animals evolved nervous systems. Collectively, these lines of evidence indicate that animals evolved nervous systems soon after the advent of macrophagy.

The fossil record testifies that animals underwent profound morphological innovations soon after they started eating each other, $550 \mathrm{MYa}$. Over the next 20 million years, we see the first appearances of teeth, claws, spines, shells, skeletons and drills. Given the first fossil appearance of highly developed eyes $525 \mathrm{MYa}$, it is plausible that nervous systems should be added to this list of innovations. The sudden increase in animal trace complexity and diversity, starting at $550 \mathrm{MYa}$, might be explained by the appearance of neurones at that time.

Before $550 \mathrm{MYa}$, it seems that animals were either filter feeders or mat grazers. Animals could have employed cheaper alternatives than neurones to meet their ecological demands. Thus, although these animals probably had much of the requisite molecular toolkit to develop ner- 
vous systems, it may not have been advantageous for them to do so.

Cnidarian, ctenophore and bilaterian nervous systems exhibit varying degrees of genetic conservation. Their ancestor must have possessed much of the core molecular toolkit required to develop a nervous system. Ancient cnidarians, ctenophores and bilaterians must have inherited that toolkit and might have used it to develop and distribute 'proto-neural' sensory cells such as those of extant sponges. If those lineages split before neurones evolved, then they must have independently co-opted their distributed 'proto-neural' sensory cells into networks of neurones. While this scenario somewhat contradicts the widespread belief that cnidarian and bilaterian neurones are genetically homologous, it potentially explains the profound developmental and design discrepancies of their nervous systems today.

\section{A Potential Utility for Fast Threshold Detectors}

Before animals ate each other, they followed gradients to find more favourable environments. When macrophagy became a viable feeding strategy, a dynamic state of the world became crucial to an animal's survival: the proximity of other animals. Knowing that state, and particularly the moment when that state indicated the presence of a threat or opportunity, would have provided utility. As soon as another animal came sufficiently close, predators and prey needed to make an immediate decision to attack or defend. That decision needed to be made at precisely the right time; striking or fleeing a bit too early or a bit too late can result in the loss of a potential meal for predators, or death for prey [Stewart et al., 2013]. Animals must have experienced a selection pressure to react as soon as they had evidence that a state of the world (e.g. the proximity of another animal) became critical.

How might that selection pressure be satisfied by spiking neurones, but not other signalling cell types? Consider a hypothetical late pre-Cambrian predator that is approaching a prey. If the prey can initiate some defensive strategy, e.g. fleeing, when the predator is some particular distance D away, it maximises its chances of surviving the encounter [Stewart et al., 2013]. Assume that the predator produces some physical signal (e.g. chemical, electrical or mechanical) that protrudes into the open environment and assume that the prey has a thresholding cell whose membrane potential depends on the strength of that signal. As the predator approaches the prey, its signal strengthens, and the membrane potential of the prey's thresholding cell rises. When the distance between the predator and prey reduces to $\mathrm{D}$, the membrane poten- tial meets its threshold, and the cell produces a spike. That spike is a precisely timed assertion that a state of the world has reached some critical value, so a decision needs to be made at that moment. Nota bene, this proposal for the origin of sensory neurones is hypothetical and abstract; it is only intended to illustrate a potential utility for fast thresholding cells in predator-prey interactions that paracrine-signalling cells cannot provide.

\section{Implications for Neural Computation}

Predator-prey interactions require animals to make precisely timed decisions in accordance with potentially fatal world states. Intuitively, animals should value realtime information about the criticality of world states, as they could make better and more precisely timed decisions in response to them. Extant sensory neurones are devices that produce spikes conditional on world states. How can an animal extract the most information about critical world states from those sensory spikes?

Since sensory spikes are conditional on world states, it is possible in principle to make inferences about the world given the presence or absence of each individual sensory spike. If an animal could implement Bayes' rule to perform this inference, then that animal would extract the most possible information about world states from sensory spikes [MacKay, 2004]. If an animal could perform Bayes' rule as quickly as sensory spikes are streamed, then that animal would have the most possible information about world states at any instant in time. In situations demanding fast decision making and reaction in accordance with potentially fatal world states, e.g. predator-prey interactions, continuous and direct inference about critical world states from sensory spikes cannot be outperformed in bits per second.

It seems plausible that nervous systems actually implement this computation, or something like it. Psychophysical evidence suggests that animals act as if they are performing bayesian inference in many tasks [Jacobs, 1999; Ernst and Banks, 2002; Weiss et al., 2002; Knill and Saunders, 2003; Adams et al., 2004; Knill and Pouget, 2004; Kording and Wolpert, 2004, 2006]. Animal reaction times indicate that individual spikes, and not trains or codes of spikes, are the fundamental operands of neural computation [Paulin and Hoffman, 2001; Uchida and Mainen, 2003; Johansson and Birznieks, 2004; Paulin, 2004; Bodelon et al., 2007; Olberg et al., 2007; Deneve, 2008; Stanford et al., 2010; Rolls and Treves, 2011]. We do not know if continuous inference from sensory spikes is biologically possible to implement, nor if the energetic expenditure required to implement it is prohibitively high. Establishing 
whether and how nervous systems might implement this computation are major open questions in neuroscience [Rao, 2004; Ma et al., 2006; Huys et al., 2007; Deneve, 2008; Ma et al., 2008; Natarajan et al., 2008; Bobrowski et al., 2009; Gerwinn et al., 2009; Fiser et al., 2010; Koyama et al., 2010; Lochmann and Deneve, 2011; Pouget et al., 2013].

\section{A Contradiction with Molecular Clocks}

Molecular clocks dispute the claim that animals evolved neurones after the advent of macrophagy. A strong argument can be made that nervous systems evolved once in bilaterians [Hirth, 2010]. If nervous systems appeared at around $550 \mathrm{MYa}$, then bilaterians must have split (into protostomes and deuterostomes) after this date. Fossil evidence does not contradict this assertion; trace fossils indicate the presence of bilaterians around $560 \mathrm{MYa}$, and the first bilaterally symmetric body fossils are dated to $557 \mathrm{MYa}$ (see Fossils and the Morphology and Behaviour of Ancient Animals). It seems reasonable that bilaterians split into protostomes and deuterostomes a few million years later. Molecular clocks, on the other hand, assert an earlier bilaterian divergence time. Current molecular clock estimates for the branching time of bilaterians into protostomes and deuterostomes range from 670 to 570 MYa [Aris-Brosou and Yang, 2003; Peterson et al., 2004, 2005; Erwin et al., 2011]. These dates imply that bilaterians remained absent from the fossil record for tens of millions of years. Either the fossil record is incomplete or the clock dates are incorrect.

Bilaterian absence from the trace fossil record for tens of millions of years seems unlikely. Before $550 \mathrm{MYa}$, there were abundant microbial mats that provided excellent taphonomic conditions to preserve traces [Gehling, 1999; Jensen et al., 2005]. It is also possible, though unlikely [Budd and Jensen, 2000], that the first bilaterians were pelagic, tiny or otherwise unable to leave detectable traces. However, the earliest bilaterian traces we observe are extremely simple, unbranched, shallow, horizontal traces depicting bilaterians gently pushing through sediment (see Fossils and the Morphology and Behaviour of Ancient Animals). These traces are inconsistent with those we would expect from organisms that had been evolving nervous systems for tens of millions of years. Furthermore, although molecular clock methods have improved, even recent results on the bilaterian split vary by 100 million years. They can be sensitive to methodology, model assumptions and the data set [Welch et al., 2005], and are unreliable when inferring earlier branching times [Marshall and Valentine, 2010]. Thus, we believe that these clock dates are too old.

Predation and the Origin of Neurones

\section{Phyla Branching Order Does Not Matter}

Phylogenetic trees produce notoriously inconsistent results [Nielsen, 2008; Siddall, 2010]. We have assumed that sponges are the most basal extant animal lineage (fig. 4). We made this assumption because most phylogenetic trees place sponges at their base [Nielsen, 2008]. We also used this assumption to provide a potential explanation for how nervous systems can be polyphyletic, yet exhibit a degree of genetic conservation. However, the core arguments of this paper do not depend on the validity of this assumption or the branching order of the animal phyla.

Recently published results indicate that ctenophores, and not sponges, could be the most basal extant animal phylum [Ryan et al., 2013; Moroz et al., 2014]. If this claim is true, it does not follow that animals evolved nervous systems once, even though extant ctenophores possess nervous systems. In fact, both Moroz et al. [2014] and Ryan et al. [2013] acknowledge this potential fallacy; if ctenophores are basal to all other animals, then either animals evolved nervous systems once, and sponges and Trichoplax subsequently lost their nervous systems, or nervous systems evolved independently in ctenophores, cnidarians and bilaterians. The latter scenario still accounts for the fossil and ecological evidence that we have reviewed in this paper.

\section{Other Proposals for Nervous System Origin}

The 'light switch' hypothesis [Parker, 1998] proposes that the evolution of sensory systems, specifically colour spatial vision, led to the onset of predation at the base of the Cambrian. We contend that causality goes the other way. Animals do not require neurones to detect gradients or move in relation to them, so animals are capable of orienting and moving toward or away from other animals by following the gradient of the signals that they emit. Thus, predation is possible in ecosystems lacking animals with neurones. Conversely, ecological considerations indicate that neurones cannot exist in ecosystems lacking predation.

Keijzer et al. [2013] argue that nervous systems evolved not as an input-output mechanism, but rather as a way to coordinate muscle contraction over large spatial scales. Their argument is based on some of the material we have presented, for example that nervous systems are not necessary for animals to detect stimuli, but does not seem to account for the fact that nervous systems are not necessary for animals to coordinate movement on large spatial scales either [Nickel et al., 2011]. Their point is well taken: a crucial function of the earliest nervous systems was to 
facilitate quick muscle contractions over the whole body. However, another crucial function was to detect the presence of states that required such coordinated contractions. Detection of states of the world and reaction to those states are inextricably linked.

Jekely [2011] proposes that the first neural circuits evolved to improve the efficiency of ciliary swimming in the ancestor of cnidarians and bilaterians. The basic idea is that, without nervous systems, sensory and motor functions are performed by the same cell, such as the photoresponsive ring of cilia in sponge larvae (fig. 3a). Each of these cells has a sensory structure whose output affects ciliary beating. The number of sensory structures can be reduced by eliminating the sensory structures of the cili- ated cells in favour of a smaller number of neurones. Those neurones produce signals in response to light intensity and transmit those signals to the ciliated cells. This transition could have allowed the diversification of sensory modalities and the behavioural repertoire of animals. While Jekely's hypothesis provides an ecological affordance for neurones, it does not explain why the first bilaterian trace fossils are so simple, given that the ancestors of those bilaterians had been evolving nervous systems for at least tens of millions of years. It also assumes that nervous systems evolved once in the cnidarian-bilaterian ancestor. Firmer molecular evidence on the monophyly or polyphyly of nervous systems should be able to support or refute his hypothesis.

\section{References}

Adams WJ, Graf EW, Ernst MO (2004): Experi- Broom M, Ruxton GD (2005): You can run - or ence can change the 'light-from-above' prior. Nat Neurosci 7:1057-1058.

-Arendt D, Denes AS, Jekely G, Tessmar-Raible K (2008): The evolution of nervous system centralization. Philos Trans R Soc Lond B Biol Sci 363:1523-1528.

-Aris-Brosou S, Yang Z (2003): Bayesian models of episodic evolution support a late Precambrian explosive diversification of the Metazoa. Mol Biol Evol 20:1947-1954.

Ball EE, Hayward DC, Saint R, Miller DJ (2004): A simple plan - cnidarians and the origins of developmental mechanisms. Nat Rev Genet 5 : 567-577.

Bengtson S (2002): Origins and early evolution of predation. Paleontol Soc Papers 8:289-317.

Bengtson S, Rasmussen B (2009): New and ancient trace makers. Science 323:346-347.

-Bengtson S, Zhao Y (1992): Predatorial borings in late Precambrian mineralized exoskeletons. Science 257:367-369.

Berg HC (1975): Chemotaxis in bacteria. Annu Rev Biophys Bioeng 4:119-136.

Bobrowski O, Meir R, Eldar YC (2009): Bayesian filtering in spiking neural networks: noise, adaptation, and multisensory integration. Neural Comput 21:1277-1320.

- Bodelon C, Fallah M, Reynolds JH (2007): Temporal resolution for the perception of features and conjunctions. J Neurosci 27:725-730.

-Borchiellini C, Manuel M, Alivon E, Boury-Esnault N, Vacelet J, Parco YL (2001): Sponge paraphyly and the origin of metazoa. J Evol Biol 14:171-179.

Bottjer DJ, Clapham ME (2006): Evolutionary Paleoecology of Ediacaran Benthic Marine Animals. Berlin, Springer, chapt 4, pp 91-114.

Brain C, Prave AR, Hoffman K-H, Fallick AE, Botha A, Herd DA, Sturrock C, Young I, Condon DJ, Allison SG (2012): The first animals: ca. 760-million-year-old sponge-like fossils from Namibia. S Afr J Sci 108:83-90. you can hide: optimal strategies for cryptic prey against pursuit predators. Behav Ecol 16 : 534-540.

Budd GE, Jensen S (2000): A critical reappraisal of the fossil record of the bilaterian phyla. Biol Rev 75:253-295.

Chemero A (2003): An outline of a theory of af-

Chen Z, Zhou C, Meyer M, Xiang K, Schiffbauer JD, Yuan X, Xiao S (2013): Trace fossil evidence for Ediacaran bilaterian animals with complex behaviors. Precambrian Res 224: 690-701.

Chittka L, Skorupski P, Raine NE (2009): Speedaccuracy tradeoffs in animal decision making. Trends Ecol Evol 24:400-407.

Clapham ME, Narbonne GM (2002): Ediacaran epifaunal tiering. Geology 30:627-630.

Clapham ME, Narbonne GM, Gehling JG (2003): Paleoecology of the oldest known animal communitites: Ediacaran assemblages at Mistaken Point, Newfoundland. Paleobiology 29: 527-544.

Clarkson E, Levi-Setti R, Horvath G (2006): The eyes of trilobites: the oldest preserved visual system. Arthropod Struct Dev 35:247-259.

Cloney RA (1982): Ascidian larvae and the events of metamorphosis. Am Zool 22:817-826.

$\checkmark$ Conway-Morris S (2006): Darwin's dilemma: the realities of the Cambrian 'explosion'. Philos Trans R Soc Lond B Biol Sci 361:1069-1083.

Cortijo I, Mus MM, Jensen S, Palacios T (2010): A new species of Cloudina from the terminal Ediacaran of Spain. Precambrian Res 176:110.

Dellaporta SL, Xu A, Sagasser S, Jakob W, Moreno MA, Buss LW, Schierwater B (2006): Mitochondrial genome of Trichoplax adhaerens supports placozoa as the basal lower metazoan phylum. Proc Natl Acad Sci USA 103: 8751-8756. fordances. Ecol Psychol 15:181-195.
Denes AS, Jekely G, Steinmetz PR, Raible F, Snyman H, Prud'homme B, Ferrier DE, Balavoine G, Arendt D (2007): Molecular architecture of annelid nerve cord supports common origin of nervous system centralization in bilateria. Cell 129:277-288.

Deneve S (2008): Bayesian spiking neurons I: inference. Neural Comput 20:91-117.

Droser ML, Gehling JG, Jensen SR (2006): Assemblage palaeoecology of the Ediacara biota: the unabridged edition? Palaeogeogr Palaeoclimatol 232:131-147.

Dunn CW, Hejnol A, Matus DQ, Pang K, Browne WE, Smith SA, Seaver E, Rouse GW, Obst M, Edgecombe GD, Sorensen MV, Haddock SHD, Schmidt-Rhaesa A, Okusu A, Kristensen RM, Wheeler WC, Martindale MQ, Giribet G (2008): Broad phylogenomic sampling improves resolution of the animal tree of life. Nature 452:745-751.

Ernst MO, Banks MS (2002): Humans integrate visual and haptic information in a statistically optimal fashion. Nature 415:429-433.

Erwin DH (2008): Wonderful Ediacarans, wonderful cnidarians? Evol Dev 10:263-264.

-Erwin DH, Laflamme M, Tweedt SM, Sperling EA, Pisani D, Peterson KJ (2011): The Cambrian conundrum: early divergence and later ecological success in the early history of animals. Science 334:1091-1097.

Ettinger-Epstein P, Whalan S, Battershill CN, de Nys R (2008): A hierarchy of settlement cues influences larval behaviour in a coral reef sponge. Mar Ecol Prog Ser 365:103-113.

Fedonkin MA, Simonetta A, Ivantsov AY (2007): New data on Kimberella, the Vendian mollusc-like organism (White Sea region, Russia): palaeoecological and evolutionary implications. Geol Soc London 286:157-179.

Fiser J, Berkes P, Orban G, Lengyel M (2010): Statistically optimal perception and learning: from behavior to neural representations. Trends Cogn Sci 14:119-130. 
Galliot B, Quiquand M (2011): A two-step process in the emergence of neurogenesis. Eur J Neurosci 34:847-862.

Galliot B, Quiquand M, Ghila L, de Rosa R, Miljkovic-Licina M, Chera S (2009): Origins of neurogenesis, a cnidarian view. Dev Biol 332:2-24.

-Gaucher C, Germs GJ (2010): Skeletonised metazoans and protists. Dev Precambrian Geol 16: 327-338.

Gehling JG (1999): Microbial mats in terminal Proterozoic siliclastics: Ediacaran death masks. Palaios 14:40-57.

-Gerwinn S, Macke J, Bethge M (2009): Bayesian population decoding of spiking neurons. Front Comput Neurosci 3:21-34.

Ghysen A (2003): The origin and evolution of the nervous system. Int J Dev Biol 47:555-562.

Gibson JJ (1979): The Ecological Approach to Visual Perception. Boston, Houghton Mifflin.

-Glenner H, Hansen AJ, Sorensen MV, Ronquist F, Huelsenbeck JP, Willerslev E (2004): Bayesian inference of the metazoan phylogeny: a combined molecular and morphological approach. Curr Biol 14:1644-1649.

-Gomez-Skarmeta JL, Campuzano S, Modolell J (2003): Half a century of neural prepatterning: the story of a few bristles and many genes. Nat Rev Neurosci 4:587-598.

-Grens A, Mason E, Marsh JL, Bode HR (1995). Evolutionary conservation of a cell fate specification gene: the Hydra achaete-scute homolog has proneural activity in Drosophila. Development 121:4027-4035.

Halanych KM (2004): The new view of animal phylogeny. Annu Rev Ecol Evol Syst 35:229256.

-Hayakawa E, Fujisawa C, Fujisawa T (2004): Involvement of Hydra achaete-scute gene $\mathrm{CnASH}$ in the differentiation pathway of sensory neurons in the tentacles. Dev Genes Evol 214:486-492.

Hirth F (2010): On the origin and evolution of the tripartite brain. Brain Behav Evol 76:3-10.

- Hua H, Pratt BR, Zhang L-Y (2003): Borings in Cloudina shells: complex predator-prey dynamics in the terminal Neoproterozoic. Palaios 18:454-459.

-Huys QJM, Zemel RS, Natarajan R, Dayan P (2007): Fast population coding. Neural Comput 19:404-441.

Ivantsov AY, Malakhovskaya YE (2002): Giant traces of Vendian animals. Doklady Earth Sci 385A:618-622.

-Jacobs D, Nakanishi N, Yuan D, Camara A, Nichols SA, Hartenstein V (2007): Evolution of sensory structures in basal Metazoa. Integr Comp Biol 47:712-723.

-Jacobs RA (1999): Optimal integration of texture and motion cues to depth. Vision Res 39: 3621-3629.

-Jekely G (2011): Origin and early evolution of neural circuits for the control of ciliary locomotion. Proc Biol Sci 278:914-922.
Jensen S (2003): The Proterozoic and earliest Cambrian trace fossil record; patterns, problems and perspectives. Integr Comp Biol 43: 219-228.

Jensen S, Droser ML, Gehling JG (2005): Trace fossil preservation and the early evolution of animals. Palaeogeogr Palaeoclimatol 220:19-29.

Jensen S, Droser ML, Gehling JG (2006): Neoproterozoic Geobiology and Paleobiology. Berlin, Springer, chapt 5, pp 115-157.

Jensen S, Saylor BZ, Gehling JG, Germs GJB (2000): Complex trace fossils from the terminal Proterozoic of Namibia. Geology 28:143146.

Johansson RS, Birznieks I (2004): First spikes in ensembles of human tactile afferents code complex spatial fingertip events. Nat Neurosci 7:170-177.

Keijzer F, van Duijn M, Lyon P (2013): What nervous systems do: early evolution, input-output, and the skin brain thesis. Adapt Behav 21: 67-85.

Knill DC, Pouget A (2004): The Bayesian brain: the role of uncertainty in neural coding and computation. Trends Neurosci 27:712-719.

Knill DC, Saunders JA (2003): Do humans optimally integrate stereo and texture information for judgments of surface slant? Vision Res 43:2539-2558.

Koizumi O, Itazawa M, Mizumoto H, Minobe S, Javois LC, Grimmelikhuijzen CJ, Bode HR (1992): Nerve ring of the hypostome in $\mathrm{Hy}$ dra. I. Its structure, development, and main tenance. J Comp Neurol 326:7-21.

Kording KP, Wolpert DM (2004): Bayesian integration in sensorimotor learning. Nature 427 244-247.

Kording KP, Wolpert DM (2006): Bayesian decision theory in sensorimotor control. Trends Cogn Sci 10:319-326.

Koyama S, Eden UT, Brown EN, Kass RE (2010): Bayesian decoding of neural spike trains. Ann Inst Stat Math 62:37-59.

Laflamme M, Narbonne GM (2008): Ediacaran fronds. Palaeogeogr Palaeoclimatol 258:162 179.

Laflamme M, Narbonne GM, Greentree C, An derson MM (2007): Morphology and taphonomy of an Ediacaran frond: Charnia from the Avalon Peninsula of Newfoundland. Geol Soc London 286:237-257.

Laughlin SB (2001): Energy as a constraint on the coding and processing of sensory information. Curr Opin Neurobiol 11:475-480.

Laughlin SB, de Ruyter van Steveninck RR, Anderson JC (1998): The metabolic cost of neural information. Nat Neurosci 1:36-41.

Leys SP, Cronin TW, Degnan BM, Marshall JN (2002): Spectral sensitivity in a sponge larva. J Comp Physiol A Neuroethol Sens Neural Behav Physiol 188:199-202.

Leys SP, Mackie GO, Meech RW (1999): Impulse conduction in a sponge. J Exp Biol 202:1139_ 1150.

Leys SP, Meech RW (2006): Physiology of coordination in sponges. Can J Zool 84:288-306.
Liebeskind BJ, Hillis DM, Zakon HH (2011): Evolution of sodium channels predates the origin of nervous systems in animals. Proc Natl Acad Sci USA 108:9154-9159.

Lindgens D, Holstein TW, Technau U (2004) Hyzic, the Hydra homolog of the zic/oddpaired gene, is involved in the early specification of the sensory nematocytes. Development 131:191-201.

Liu AG, McIlroy D, Brasier MD (2010): First evidence for locomotion in the Ediacara biota from the $565 \mathrm{Ma}$ Mistaken Point Formation, Newfoundland. Geology 38:123-126.

Lochmann T, Deneve S (2011): Neural processing as causal inference. Curr Opin Neurobiol 21: $774-781$

Love GD, Grosjean E, Stalvies C, Fike DA, Grotzinger JP, Bradley AS, Kelly AE, Bhatia M, Meredith W, Snape CE, Bowring SA, Condon DJ, Summons RE (2009): Fossil steroids record the appearance of Demospongiae during the Cryogenian period. Nature 457:718-722.

-Lowe CJ, Wu M, Salic A, Evans L, Lander E, Strange-Thomann N, Gruber CE, Gerhart J, Kirschner M (2003): Anteroposterior patterning in hemichordates and the origins of the chordate nervous system. Cell 113:853865

Ludeman DA, Farrar N, Riesgo A, Paps J, Leys SP (2014): Evolutionary origins of sensation in metazoans: functional evidence for a new sensory organ in sponges. BMC Evol Biol 14:3.

Ma WJ, Beck JM, Latham PE, Pouget A (2006): Bayesian inference with probabilistic population codes. Nat Neurosci 9:1432-1438.

-Ma WJ, Beck JM, Pouget A (2008): Spiking networks for Bayesian inference and choice. Curr Opin Neurobiol 18:217-222.

MacKay DJC (2004): Information Theory, Inference, and Learning Algorithms. Cambridge, Cambridge University Press.

Maldonado M (2004): Choanoflagellates, choanocytes, and animal multicellularity. Invertebr Biol 123:1-22.

Maldonado M (2006): The ecology of the sponge larva. Can J Zool 84:175-194.

Maldonado M, Durfort M, McCarthy DA, Young CM (2003): The cellular basis of photobehavior in the tufted parenchymella larva of demosponges. Mar Biol 143:427-441.

- Maloof AC, Porter SM, Moore JL, Dudas FO, Bowring SA, Higgins JA, Fike DA, Eddy MP (2010): The earliest Cambrian record of animals and ocean geochemical change. Geol Soc Am Bull 122(11/12):1731-1774.

Mangano MG, Buatois LA (2007): Trace Fossils in Evolutionary Paleoecology. Amsterdam, Elsevier, chapt 23, pp 391-409.

Manuel M, Borchiellini C, Alivon E, Parco YL, Vacelet J, Boury-Esnault N (2003): Phylogeny and evolution of calcareous sponges: monophyly of calcinea and calcaronea, high level of morphological homoplasy, and the primitive nature of axial symmetry. Syst Biol 52:311333. 
- Marlow HQ, Srivastava M, Matus DQ, Rokhsar D, Martindale MQ (2009): Anatomy and development of the nervous system of Nematostella vectensis, an anthozoan cnidarian. Dev Neurobiol 69:235-254.

Marshall CR, Valentine JW (2010): The importance of preadapted genomes in the origin of the animal bodyplans and the Cambrian explosion. Evolution 64:1189-1201.

-Matus DQ, Pang K, Marlow H, Dunn CW, Thomsen GH, Martindale MQ (2006): Molecular evidence for deep evolutionary roots of bilateriality in animal development. Proc Natl Acad Sci USA 103:11195-11200.

-McCall G (2006): The Vendian (Ediacaran) in the geological record: enigmas in geology's prelude to the Cambrian explosion. Earth Sci Rev 77:1-229.

McIlroy D, Brasier MD, Lang AS (2009): Smothering of microbial mats by macrobiota: implications for the Ediacara biota. J Geol Soc London 166:1117-1121.

McMenamin MAS (1986): The garden of Ediacara. Palaios 1:178-182.

Moroz LL (2009): On the independent origins of complex brains and neurons. Brain Behav Evol 74:177-190.

-Moroz LL, Kocot KM, Citarella MR, Dosung S, Norekian TP, Povolotskaya IS, Grigorenko AP, Dailey C, Berezikov E, Buckley KM, Ptitsyn A, Reshetov D, Mukherjee K, Moroz TP, Bobkova Y, Yu F, Kapitonov VV, Jurka J, Bobkov YV, Swore JJ, Girardo DO, Fodor A, Gusev F, Sanford R, Bruders R, Kittler E, Mills CE, Rast JP, Derelle R, Solvyev VV, Kondrashov FA, Swalla BJ, Sweedler JV, Rogaev EI, Halanych KM, Kohn AB (2014): The ctenophore genome and the evolutionary origins of neural systems. Nature 510:109-114.

Muller WE (2001): Review: how was metazoan threshold crossed? The hypothetical Urmetazoa. Comp Biochem Physiol A Mol Integr Physiol 129:433-460.

Muller WE (2003): The origin of metazoan complexity: Porifera as integrated animals. Integr Comp Biol 43:3-10.

- Nakanishi N, Renfer E, Technau U, Rentzsch F (2012): Nervous systems of the sea anemone Nematostella vectensis are generated by ectoderm and endoderm and shaped by distinct mechanisms. Development 139:347-357.

-Narbonne GM (2005): The Ediacara biota: Neoproterozoic origin of animals and their ecosystems. Annu Rev Earth Planet Sci 33:421442.

- Natarajan R, Huys QJM, Dayan P, Zemel RS (2008): Encoding and decoding spikes for dynamic stimuli. Neural Comput 20:2325-2360.

- Nickel M (2010): Evolutionary emergence of synaptic nervous systems: what can we learn from the non-synaptic, nerveless Porifera? Invertebr Biol 129:1-16.

-Nickel M, Scheer C, Hammel JU, Herzen J, Beckmann F (2011): The contractile sponge epithelium sensu lato - body contraction of the demosponge Tethya wilhelma is mediated by the pinacoderm. J Exp Biol 214:1692-1698.
Nielsen C (2008): Six major steps in animal evolution: are we derived sponge larvae? Evol Dev 10:241-257.

Niven JE, Anderson JC, Laughlin SB (2007): Fly photoreceptors demonstrate energy-information trade-offs in neural coding. PLoS Biol 5:e116.

Niven JE, Laughlin SB (2008): Energy limitation as a selective pressure on the evolution of sensory systems. J Exp Biol 211:1792-1804.

Northcutt RG (2012): Evolution of centralized nervous systems: two schools of evolutionary thought. Proc Natl Acad Sci USA 109:1062610633.

Olberg RM, Seaman RC, Coats MI, Henry AF (2007): Eye movements and target fixation during dragonfly prey-interception flights. J Comp Physiol A Neuroethol Sens Neural Behav Physiol 193:685-693.

Parker AR (1998): Colour in Burgess Shale animals and the effect of light on evolution in the Cambrian. Proc Biol Sci 265:967-972.

Paterson JR, Garcia-Bellido DC, Lee MSY, Brock GA, Jago JB, Edgecombe GD (2011): Acute vision in the giant Cambrian predator Anomalocaris and the origin of compound eyes. Nature 480:237-240.

Paulin M (2004): Spikes are the operands of neural computation. Neural Netw Soc Newsl 2: $1-4$.

Paulin MG, Hoffman LF (2001): State-space receptive fields of semicircular canal afferent neurons in the bullfrog. Neurocomputing 38 40:293-298

Pearse VB, Voigt O (2007): Field biology of placozoans (Trichoplax): distribution, diversity, biotic interactions. Integr Comp Biol 47:677692.

Peterson KJ, Butterfield NJ (2005): Origin of the Eumetazoa: testing ecological predictions of molecular clocks against the Proterozoic fossil record. Proc Natl Acad Sci USA 102:95479552.

- Peterson KJ, Cotton JA, Gehling JG, Pisani D (2008): The Ediacaran emergence of bilaterians: congruence between the genetic and the geological fossil records. Philos Trans R Soc Lond B Biol Sci 363:1435-1443.

Peterson KJ, Eernisse DJ (2001): Animal phylog eny and the ancestry of bilaterians: inferences from morphology and 18S rDNA gene sequences. Evol Dev 3:170-205.

- Peterson KJ, Lyons JB, Nowak KS, Takacs CM, Wargo MJ, McPeek MA (2004): Estimating metazoan divergence times with a molecular clock. Proc Natl Acad Sci USA 101:65366541.

Peterson KJ, McPeek MA, Evans DAD (2005): Tempo and mode of early animal evolution: inferences from rocks, Hox, and molecular clocks. Paleobiology 31(2-suppl):36-55.

Phillippe H, Derelle R, Lopez P, Pick K, Borchiellini C, Boury-Esnault N, Vacelet J, Renard E, Houliston E, Queinnec E, Silva CD, Wincker P, Guyader HL, Leys SP, Jackson DJ, Schreiber F, Erpenbeck D, Morgenstern B, Worheide G, Manuel M (2009): Phylogenomics re- vives traditional views on deep animal relationships. Curr Biol 19:706-712.

Plotnick RE (2012): Behavioral biology of trace fossils. Paleobiology 38:459-473.

Pouget A, Beck JM, Ma WJ, Latham PE (2013): Probabilistic brains: knowns and unknowns. Nat Neurosci 16:1170-1178.

Rao RPN (2004): Bayesian computation in recurrent neural circuits. Neural Comput 16:1-38.

Renard E, Vacelet J, Gazave E, Lapebie P, Borchiellini C, Ereskovsky AV (2009): Origin of the neuro-sensory system: new and expected insights from sponges. Integr Zool 4:294-308.

Richards GS, Simionato E, Perron M, Adamska M, Vervoort M, Degnan BM (2008): Sponge genes provide new insight into the evolutionary origin of the neurogenic circuit. Curr Biol 18:1156-1161.

-Rivera AS, Ozturk N, Fahey B, Plachetzki DC, Degnan BM, Sancar A, Oakley TH (2012): Blue-light-receptive cryptochrome is expressed in a sponge eye lacking neurons and opsin. J Exp Biol 215:1278-1286.

Rolls ET, Treves A (2011): The neural encoding of information in the brain. Prog Neurobiol 95: 448-490.

Ryan JF, Pang K, Schnitzler CE, Nguyen A-D, Moreland RT, Simmons DK, Koch BJ, Francis WR, Havlak P, Smith SA, Putnam NH, Haddock SHD, Dunn CW, Wolfsberg TG, Mullikin JC, Martindale MQ, Baxevanis AD (2013): The genome of the ctenophore Mnemiopsis leidyi and its implications for cell type evolution. Science 342:1336-1343.

- Sakarya O, Armstrong KA, Adamska M, Adamski M, Wang I-F, Tidor B, Degnan BM, Oakley TH, Kosik KS (2007): A post-synaptic scaffold at the origin of the animal kingdom. PLoS One 2:e506.

Schierwater B (2005): My favorite animal, Trichoplax adhaerens. BioEssays 27:1294-1302.

-Schierwater B, Kamm K, Srivastava M, Rokhsar D, Rosengarten RD, Dellaporta SL (2008): The early ANTP gene repertoire: insights from the placozoan genome. PLoS One 3:e2457.

-Seilacher A (1999): Biomat-related lifestyles in the Precambrian. Palaios 14:86-93.

- Seilacher A, Buatois LA, Mangano MG (2005): Trace fossils in the Ediacaran-Cambrian transition: behavioral diversification, ecological turnover and environmental shift. Palaeogeogr Palaeoclimatol 227:323-356.

Serezhnikova EA (2007): Palaeophragmodictya spinosa sp. nov., a bilateral benthic organism from the Vendian of the southeastern White Sea region. Paleontol J 41:360-369.

Shen B, Dong L, Xiao S, Kowalewski M (2008): The Avalon explosion: evolution of Ediacara morphospace. Science 319:81-84.

-Siddall ME (2010): Unringing a bell: metazoan phylogenomics and the partition bootstrap. Cladistics 26:444-452.

Sperling E, Pisani D, Peterson KJ (2012): Poriferan paraphyly and its implications for Precambrian palaeobiology. Geol Soc London 286:355-368 
Sperling EA, Frieder CA, Raman AV, Girguis PR, Levin LA, Knoll AH (2013): Oxygen, ecology, and the Cambrian radiation of animals. Proc Natl Acad Sci USA 110:13446-13451.

-Srivastava M, Begovic E, Chapman J, Putnam NH, Hellsten U, Kawashima T, Kuo A, Mitros T, Salamov A, Carpenter ML, Signorovitch AY, Moreno MA, Kamm K, Grimwood J, Schmutz J, Shapiro H, Grigoriev IV, Buss LW, Schierwater B, Dellaporta SL, Rokhsar DS (2008): The Trichoplax genome and the nature of placozoans. Nature 454:955-960.

-Stanford TR, Shankar S, Massoglia DP, Costello MG, Salinas E (2010): Perceptual decision making in less than 30 milliseconds. Nat Neurosci 13:379-385.

-Stewart WJ, Cardenas GS, McHenry MJ (2013): Zebrafish larvae evade predators by sensing water flow. J Exp Biol 216:388-398.

Tang F, Bengtson S, Wang Y, Wang X-L, Yin C-Y (2011): Eoandromeda and the origin of Ctenophora. Evol Dev 13:408-414.

Tompkins-MacDonald GJ, Gallin WJ, Sakarya O, Degnan B, Leys SP, Boland LM (2009): Expression of a poriferan potassium channel: insights into the evolution of ion channels in metazoans. J Exp Biol 212:761-767.
Trewavas A (2005): Plant intelligence. Naturwissenschaften 92:401-413.

Uchida N, Mainen ZF (2003): Speed and accuracy of olfactory discrimination in the rat. Nat Neurosci 6:1224-1229.

Valentine JW (2002): Prelude to the Cambrian explosion. Annu Rev Earth Planet Sci 30:285306.

Waggoner B (1998): Interpreting the earliest metazoan fossils: what can we learn? Am Zool 38:975-982.

-Waggoner B (2003): The Ediacaran biotas in space and time. Integr Comp Biol 43:104113.

Wahab MAA, de Nys R, Whalan S (2011): Larval behaviour and settlement cues of a brooding coral reef sponge. Coral Reefs 30:451-460.

Wallberg A, Thollesson M, Farris JS, Jondelius U (2004): The phylogenetic position of the comb jellies (Ctenophora) and the importance of taxonomic sampling. Cladistics 20: 558-578.

Watanabe H, Fujisawa T, Holstein TW (2009): Cnidarians and the evolutionary origin of the nervous system. Dev Growth Differ 51:167183.

Weiss Y, Simoncelli EP, Adelson EH (2002): Motion illusions as optimal percepts. Nat Neurosci 5:598-604.
-Welch JJ, Fontanillas E, Bromham L (2005): Molecular dates for the 'Cambrian explosion': the influence of prior assumptions. Syst Biol 54: 672-678.

Wood RA (2011): Paleoecology of the earliest skeletal metazoan communities: implications for early biomineralization. Earth Sci Rev 106: 184-190.

Woollacott RM (1993): Structure and swimming behavior of the larva of Haliclona tubifera (Porifera: Demospongiae). J Morphol 218: 301-321.

Xiao S, Laflamme M (2008): On the eve of animal radiation: phylogeny, ecology and evolution of the Ediacara biota. Trends Ecol Evol 24: 31-40.

Zhang X, Shu D (2007): Soft anatomy of Sunellid arthropods from the Chengjiang Lagerstatte, lower Cambrian of southwest China. J Paleontol 81:1412-1422.

Zhu M, Gehling JG, Xiao S, Zhao Y, Droser ML (2008): Eight-armed Ediacara fossil preserved in contrasting taphonomic windows from China and Australia. Geology 36:867-870.

Zylberberg J, DeWeese MR (2011): How should prey animals respond to uncertain threats? Front Comput Neurosci 5:20-27. 